\title{
Peningkatan Kapasitas Keterampilan Teknologi Informasi Bagi Pengelola Komunitas Sahabat Penyu
}

\author{
Indrabayu*, Intan Sari Areni, Ingrid Nurtanio, Amil A. Ilham, Christoforus Yohannes \\ Departemen Teknik Informatika, Fakultas Teknik UNHAS \\ indrabayu@unhas.ac.id*
}

\begin{abstract}
Abstrak
Komunitas Sahabat Penyu di Dusun Mampie Kabupaten Polewali Mandar (Polman) adalah kumpulan masyarakat yang aktif dalam kegiatan pelestarian penyu dengan mengumpulkan telur penyu, melakukan penetasan, perawatan serta rehabilitas penyu guna menjaga populasi penyu yang semakin berkurang di daerah tersebut. Hal ini bertujuan untuk melestarikan penyu mengingat semakin berkurangnya populasi penyu yang ada di Polman khususnya di Dusun Mampie. Kegiatan yang dilakukan melalui pendekatan ke sejumlah pemuda dan masyarakat lainya yang selama ini aktif menjual telur penyu ke pasaran untuk tidak lagi memperjual-belikan telur tersebut. Kurangnya kesadaran masyarakat akan manajemen konservasi penyu, proses monitoring jumlah dan perkembangbiakan telur penyu yang masih bersifat tradisional serta permasalahan pendanaan yang masih sangat minim merupakan masalah yang dihadapi oleh Komunitas Sahabat Penyu. Oleh karena itu, kegiatan pengabdian ini menawarkan solusi terkait peningkatan keterampilan para anggota komunitas dalam hal Teknologi Informasi untuk peningkatan kesadaran masyarakat terkait konservasi penyu. Tujuan kegiatan Pengabdian pada Masyarakat ini adalah memberikan pengenalan keterampilan dan pelatihan Teknologi Informasi kepada komunitas Sahabat Penyu tentang pembuatan sistem informasi berbasis website dengan media Wix. Media ini adalah sebuah aplikasi yang telah banyak digunakan untuk membuat website mulai dari blog, online shop, corporate website, serta situs edukasi. Selain itu, pelatihan desain media periklanan sederhana juga diberikan, yaitu pembuatan brosur, pamphlet, poster dan flyer. Dengan keterampilan yang diperoleh dari proses pelatihan Teknologi Informasi yang diberikan oleh tim pengabdian Departemen Teknik Informatika dan Departemen Teknik Elektro Universitas Hasanuddin maka komunitas Sahabat Penyu dapat menciptakan sistem informasi komunitas yang dapat berfungsi sebagai ajang promosi komunitas untuk menjaga eksistensi sehingga otomatis dapat menumbuhkan kesadaran akan pelestarian populasi penyu dan meningkatkan donasi kepeduliaan masyarakat terhadap penyu.
\end{abstract}

Kata Kunci: Komunitas Penyu; Teknologi Informasi; Pengabdian

\section{Pendahuluan}

Kabupaten Polewali Mandar (Polman) secara administratif merupakan salah satu kabupaten dalam wilayah Provinsi Sulawesi Barat. Dengan luas perairan $86.921 \mathrm{~km}^{2}$ dan panjang garis pantai sekitar 89,07 km. Salah satu daya tarik Polewali Mandar memiliki garis pantai yang memanjang dan sebagian besar merupakan kawasan wisata pantai seperti Pantai Mampie. Karakteristik wilayah laut tersebut menyebabkan Kabupaten Polewali mandar memiliki beragam habitat baik terumbu karang, ikan, gastropoda, molusca dan jenis crustazea. Sebagian besar wilayah perairan dan pantai di Sulawesi Barat merupakan tempat pendaratan Penyu untuk bertelur, diantaranya jenis penyu sisik (Eretmochelys imbricata), penyu hijau (Chelonia mydas) dan penyu lekang (Lepidochelys olivacea) (Sahabat Penyu, 2015).

Di Kabupaten Polewali Mandar, salah satu area peneluran penyu secara alamiah yaitu Dusun Mampie yang terletak di Desa Galeso, Kecamatan Wonomulyo. Lokasi itu memiliki topografi pantai yang lebih landai, dengan pasir putih yang memanjang dari arah Timur ke Barat sehingga memungkinkan bagi penyu untuk melakukan peneluran. Menurut masyarakat setempat, peneluran penyu di kawasan tersebut sudah mulai diketahui sejak tahun 1980-an. Ada pun jenis penyu yang bertelur di Dusun Mampie yaitu penyu sisik (Eretmochelys imbricata), penyu hijau (Chelonia mydas) dan penyu lekang (Lepidochelys olivacea) (Sahabat Penyu, 2015). 
Sejak 2013, masyarakat yang tergabung dalam komunitas Sahabat Penyu di Dusun Mampie melakukan kegiatan pelestarian dengan cara membeli telur penyu dari masyarakat yang setiap malamnya melakukan pencarian telur penyu. Hal ini bertujuan untuk melestarikan penyu mengingat semakin berkurangnya populasi penyu yang ada di Polman khususnya di Dusun Mampie. Kegiatan yang dilakukan melalui pendekatan ke sejumlah pemuda dan masyarakat lainya yang selama ini aktif menjual telur penyu ke pasaran untuk tidak lagi memperjualbelikan telur tersebut. Upaya tersebut sedikit ada perubahan pada masyarakat yang sejak dua tiga tahun terakhir.

Saat ini komunitas Sahabat Penyu telah melakukan zonasi pada area peneluran dan memainkan peran sebagai tempat transit bagi proses reproduksi penyu. Sahabat Penyu bersama anggotanya mengumpulkan telur penyu dari zonasi pantai saat musim telur tiba yaitu sekitar bulan Maret hingga bulan Juli. Telur-telur tersebut lalu ditetaskan dan dipelihara antara 1-3 bulan, tergantung kemampuan pendanaan Sahabat Penyu. Di samping melakukan penetasan dan perawatan tukik yang sakit, komunitas ini juga melakukan rehabilitas penyu yang acapkali ditemukan oleh masyarakat atau di tangkap/sita oleh pihak penegak hukum dari masyarakat. Anggota sahabat penyu diperlihatkan pada Gambar 1.

Harapan besar Sahabat Penyu dapat menjadi pusat pendidikan dan konservasi penyu di Kabupaten Polewali Mandar secara khusus dan di Sulawesi Barat pada umumnya. Oleh karena itu, penyiapan sarana dan prasarana merupakan salah satu bagian dari upaya menuju pencapaian visi Sahabat Penyu. Salah satu skill yang diperlukan dalam komunitas ini adalah dengan melibatkan Teknologi Informasi untuk mengenalkan kegiatan pelestarian penyu ini. Salah satu teknologi yang dapat dikembangkan yaitu dengan sistem informasi komunitas berbasis website.

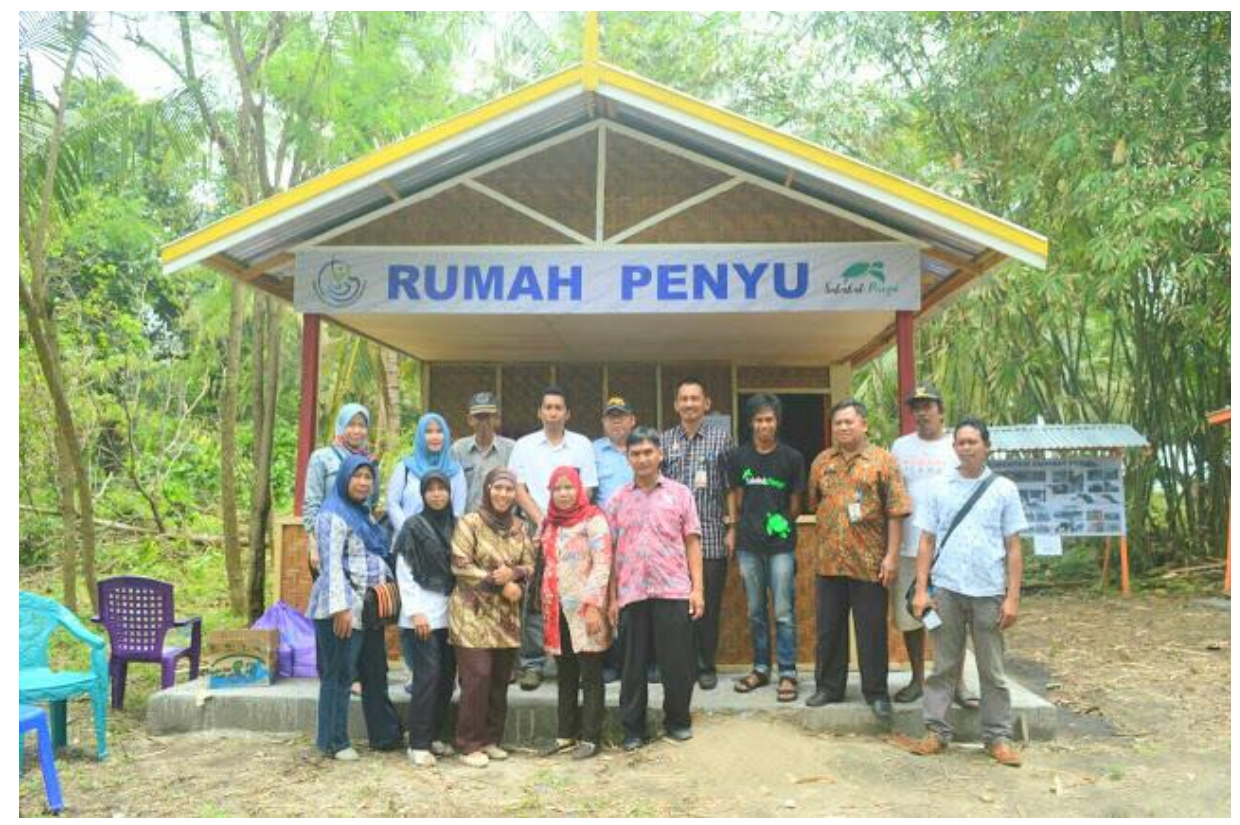

Gambar 1. Rumah Penyu yang didirikan oleh komunitas Penyu

Penelitian yang dilakukan oleh Nurpandi dan Kurniawan tahun 2016 juga mengembangkan sistem informasi berbasis website serupa tetapi untuk pembudidayaan Ikan di Balai Pelestarian. Sistem seperti ini dikembangkan dengan tujuan untuk mempermudah proses pengelolaan data ikan yang akan dilestarikan (Nurpandi dan Kurniawan, 2016). Website adalah kumpulan halaman yang menampilkan informasi data teks, data gambar, data diam 
atau bergerak, data animasi, data suara dan atau gabungan semuanya, baik yang bersifat statis maupun dinamis yang membentuk satu rangkaian yang saling terkait dan masing-masing dihubungkan dengan jaringan-jaringan halaman (hyperlink) (Anjarkusuma dan Soepeno, 2014). Salah satu media dalam membuat website yaitu WIX. Media berbasis web ini biasanya digunakan sebagai blog pribadi, situs perusahaan (company profile), situs edukasi, bahkan situs penjualan. Dengan kemampuan merancang dan mengembangkan website ini tentunya akan memberikan manfaat lebih bagi pengenalan komunitas Sahabat Penyu dalam melestarikan penyu-penyu yang ada di dusun Mampie. Selain itu, dengan memunculkan informasi komunitas ini di dunia maya bukan tidak mungkin donatur akan bertambah banyak seiring dengan kepedulian masyarakat akan wujud pelestarian hewan ini.

Oleh karena itu, kami dari tim Pengabdian kepada Masyarakat dari Program Studi Teknik Informatika dan Program Studi Teknik Elektro Universitas Hasanuddin melakukan pelatihan Teknologi Informasi untuk perancangan dan pengembangan sistem informasi berbasis website menggunakan WIX yang dapat membantu pengelolaan administrasi komunitas Sahabat Penyu dan juga sebagai ajang promosi komunitas untuk menjaga eksistensi, meningkatkan kesadaran terhadap pelestarian biota laut ini serta meningkatkan donasi kepeduliaan masyarakat terhadap penyu di dusun Mampie Kabupaten Polewali Mandar.

Dengan sarana dan prasarana yang lebih lengkap, Sahabat Penyu dapat memulai langkahlangkah yang tidak hanya berkutat pada upaya-upaya tradisional seperti penangkaran dan pemeliharaan, tetapi melangkah menjadi wadah pendidikan lingkungan dan konservasi terutama kepada anak-anak dan generasi muda dengan pemanfaatan Teknologi Informasi.

\section{Latar Belakang Teori}

Komunitas Sahabat Penyu yang berada di dusun Mampie Kabupaten Polewali Mandar sekarang ini telah melakukan kegiatan pelestarian penyu. Setelah melakukan komunikasi dengan anggota komunitas tersebut, maka yang menjadi permasalahan utama yang dihadapi adalah:

a. Rendahnya kesadaran masyarakat di desa-desa sekitar kawasan yang masih seringkali melakukan perburuan secara illegal terhadap penyu.

b. Masih lemahnya proses administrasi kegiatan, khususnya pencatatan terkait dengan teknis mulai dari monitoring, jumlah telur dan penandaan lokasi yang menjadi aktivitas penyu bertelur

c. Masalah pendanaan yang masih sangat tergantung dari kontribusi para donator dan Anggota Sahabat Penyu.

Berdasarkan permasalahan yang dihadapi mitra maka beberapa solusi yang ditawarkan sebagai usaha untuk memecahkan masalah yang dihadapi diuraikan sebagai berikut.

a. Pengenalan keterampilan Teknologi Informasi untuk mendukung promosi komunitas Sahabat Penyu sehingga kegiatan rutin yang dilakukan dapat lebih dikenal secara luas. Pengenalan aplikasi database sederhana untuk pendataan yang akurat dan sistematis.

b. Pelatihan pembuatan website dengan WIX, yang diperlihatkan pada Gambar 2, untuk sistem informasi komunitas pelestarian penyu. Memudahkan sosialisasi yang interaktif dan menjangkau area yang luas dan memberikan high impact. 


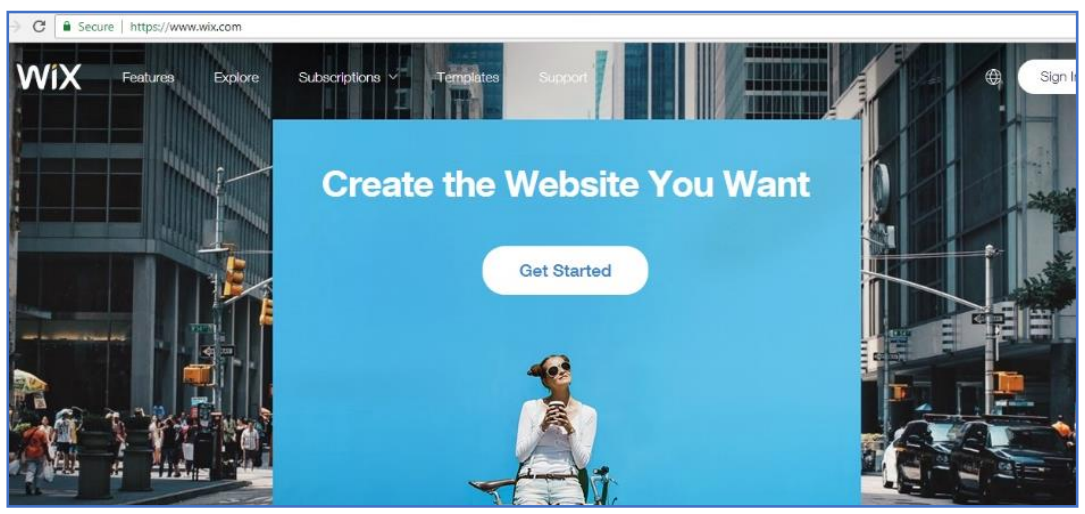

Gambar 2. Template pembuatan website dengan WIX

\section{Metode}

Usaha-usaha yang telah dilakukan untuk memecahkan masalah yang dihadapi oleh komunitas Sahabat Penyu di Kabupaten Polewali Mandar khususnya dusun Mampie adalah dengan melakukan sosialisasi dan pelatihan bagi komunitas tersebut dengan uraian sebagai berikut.

a. Melakukan pengenalan keterampilan Teknologi Informasi untuk mendukung promosi komunitas Sahabat Penyu sehingga kegiatan rutin yang dilakukan dapat lebih dikenal secara luas.

b. Melakukan pelatihan pembuatan website untuk sistem informasi komunitas pelestarian penyu.

\section{Hasil dan Diskusi}

Kegiatan pengabdian pada masyarakat di Komunitas Sahabat Penyu di Kabupaten Polewali Sulawesi Barat telah dilakukan pada Kamis, 2 Agustus 2018. Pelatihan pembuatan Web dihadiri oleh 10 orang anggota komunitas sahabat penyu. Pelatihan yang dilakukan dibagi dalam 2 sesi, yaitu pelatihan pembuatan website seperti yang ditunjukkan pada Gambar 3 dan pelatihan pembuatan media periklanan seperti pada Gambar 4.

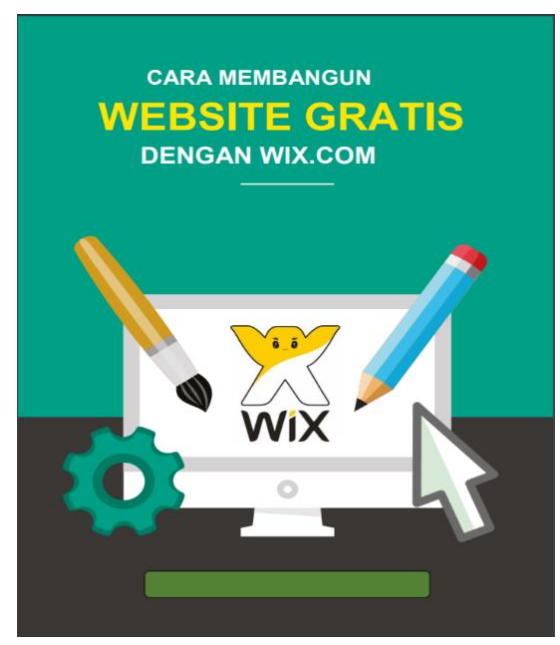

Gambar 3. Sesi 1: Pelatihan Pembuatan Website 


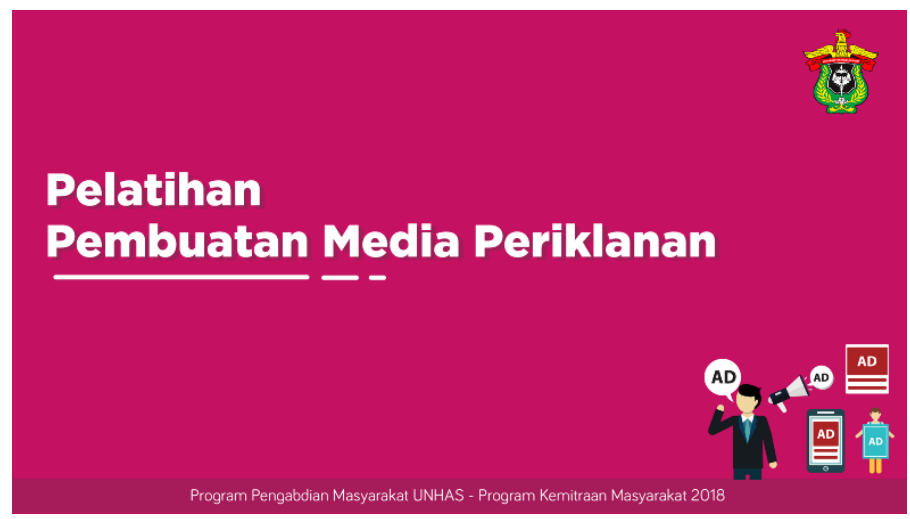

Gambar 4. Sesi 2: Pelatihan Pembuatan Media Periklanan.

Dokumentasi kegiatan diperlihatkan pada Gambar 5 berikut dan publikasi pelatihan yang dipublikasi pada media online "Tribun".

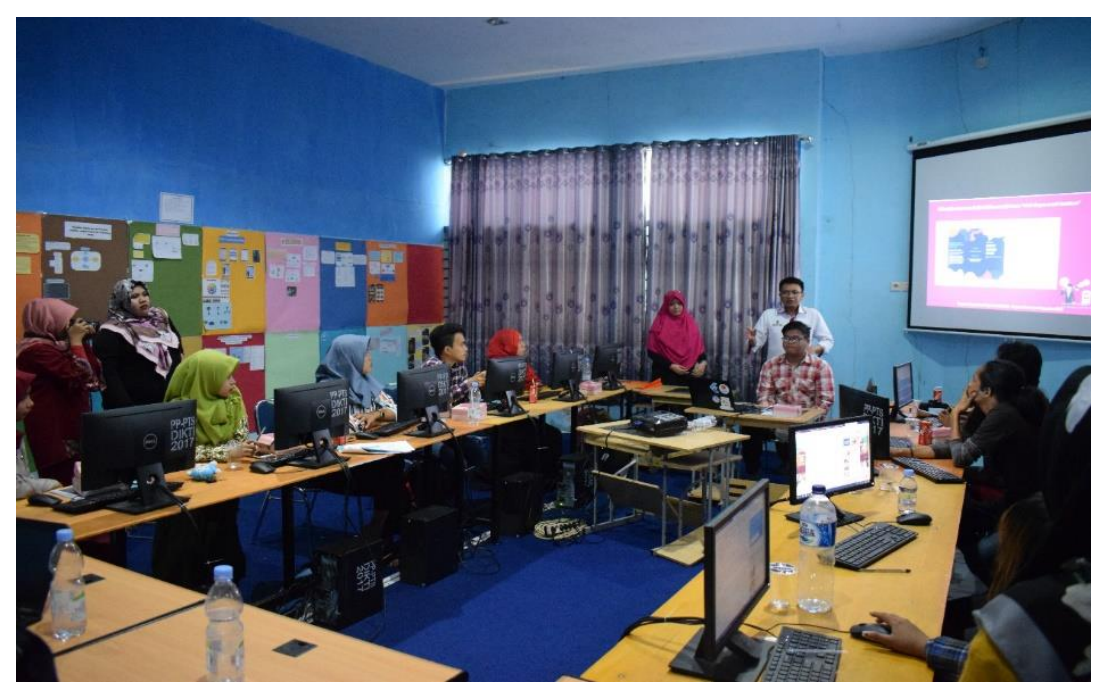

Gambar 5(a). Dokumentasi kegiatan

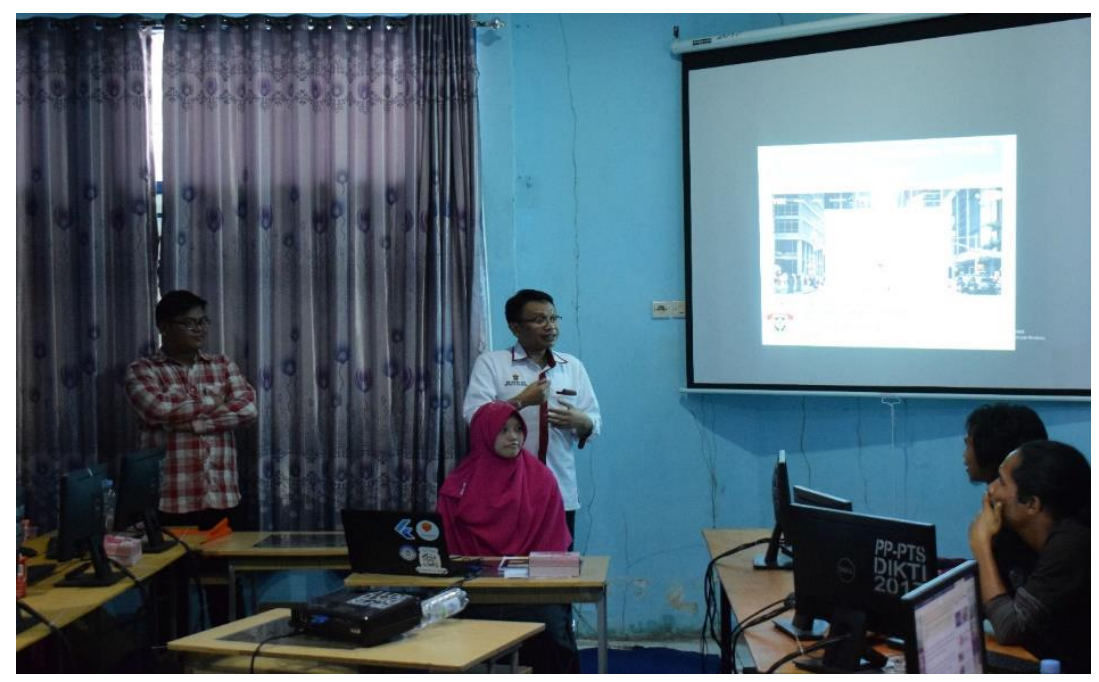

Gambar 5(b). Dokumentasi kegiatan 


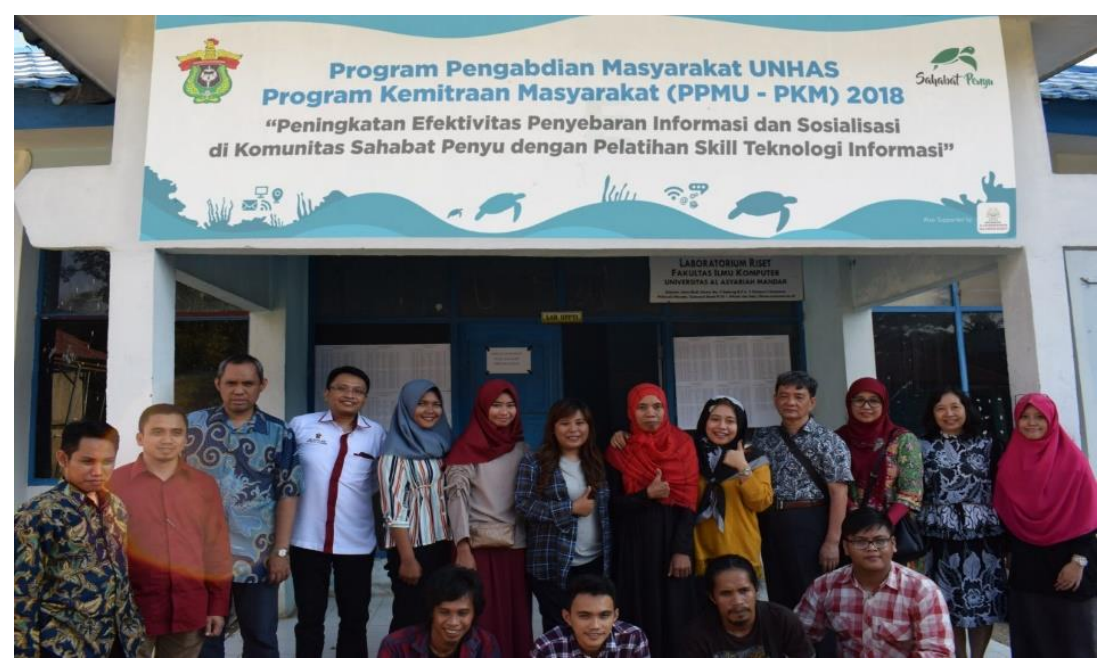

Gambar 5(c). Dokumentasi kegiatan

\section{Kesimpulan}

Kegiatan Pengabdian kepada Masyarakat telah dilakukan oleh tim pengabdian dari Departemen Teknik Informatika dan Teknik Elektro dalam bentuk Sosialisasi dan pelatihan pembuatan website dan pembuatan media periklanan pada komunitas Sahabat Penyu di Polewali Mandar yang dihadiri oleh 10 orang anggota komunitas. Kegiatan ini merupakan solusi dari permasalahan yang dihadapi oleh komunitas Sahabat Penyu untuk mendukung promosi komunitas sehingga kegiatan rutin yang dilakukan dapat lebih dikenal secara luas.

\section{Ucapan Terima Kasih}

Penulis mengucapkan terima kasih kepada mitra khususnya managerial dari Komunitas Sahabat Penyu atas kerja samanya dalam pelaksanaan kegiatan pengabdian ini. Selain itu, penulis juga mengucapkan terima kasih kepada Lembaga Penelitian dan Pengabdian Kepada Masyarakat (LPPM) Universitas Hasanuddin yang telah memberikan pembiayaan dalam bentuk hibah PPMU-PKM (Program Pengabdian kepada Masyarakat UNHAS-Program Kemitraan Masyarakat).

\section{Daftar Pusaka}

Anjarkusuma, D dan Soepeno, B. (2014). Penggunaan Aplikasi CMS Wordpress untuk merancang Website sebagai Media Promosi pada Maroon Wedding Malang. Jurnal Akuntasi, Ekonomi, dan Manajemen Bisnis, Vol. 2 No. 1.

Nurpandi, F dan Kurniawan, H. (2016). Sistem Informasi Pembudidayaan Ikan di Balai Pelestarian Perikanan Perairan Umum dan Pengembangan Ikan Hias Ciherang Cianjur. Media Jurnal Informatika, Vol. 8 No. 2.

Sahabat Penyu. (2015). Profil Sahabat Penyu. Komunitas Konservasi Penyu Dusun Mampie. Sulawesi Mandar. 